\title{
TEACHERS' PEDAGOGIC COMPETENCE AT SD NEGERI 168 PEKANBARU
}

\author{
Ayu Puspitaningsari ${ }^{1}$, Zufriady $^{2}$ \\ ${ }^{1,2}$ Universitas Riau, Pekanbaru, Indonesia \\ lapuspitaningsari@gmail.com, ${ }^{2}$ zufriady@lecturer.unri.ac.id
}

\begin{abstract}
The purpose of this research was to describe the teachers' pedagogic competence at Sekolah dasar Negeri 168 Pekanbaru. This research was conducted on July 2020. The type of this research was quantitative which provided the description about the current condition on the research object which was the teachers' pedagogic competence at Sekolah dasar Negeri 168 Pekanbaru. The sampling techniques applied in this research was a saturated sampling. The samples of this research were all teachers of ekolah dasar Negeri 168 Pekanbaru amounted 15 teachers. Data were collected through a 71-items questionnaire via google form with the instrument of a positive and negative statement about teachers' pedagogic competence with four alternative answers. The research results concluded that the teachers' pedagogic competence at Sekolah dasar Negeri 168 Pekanbaru reached $87.62 \%$ with "Very Good" category. The number of core competency who scored in the interval 85-100 with the category of "Very Good" were 7 core competency, at intervals of 70-84 with the category "Good" were 3 core competency, at intervals of 50-69 with the category "Enough" was 0, and at interval of 0-49 with the category "Less" was also 0.
\end{abstract}

Keywords: teachers' pedagogic competence

\section{KOMPETENSI PEDAGOGIK GURU SEKOLAH DASAR NEGERI 168 KOTA PEKANBARU}

\begin{abstract}
ABSTRAK
Tujuan penelitian ini adalah untuk mendeskripsikan kompetensi pedagogik Guru Sekolah Dasar Negeri 168 Kota Pekanbaru. Penelitian ini dilakukan di Sekolah Dasar 168 Kota Pekanbaru pada Juli 2020. Jenis penelitian adalah kuantitatif yang memberikan gambaran tentang keadaan yang sedang berlangsung pada objek penelitian yaitu Kompetensi Pedagogik Guru Sekolah Dasar Negeri 168 Kota Pekanbaru. Pengambilan sampel dalam penelitian ini dengan menggunakan teknik sampling jenuh. Sampel yang digunakan yaitu seluruh guru Sekolah Dasar Negeri 168 Kota Pekanbaru yang berjumlah 15 orang guru. Teknik pengumpulan data yang digunakan adalah teknik angket melalui media google form dengan instrumen penelitian ini berupa pernyataan positif dan negatif tentang kompetensi pedagogik guru dengan empat alternatif jawaban dengan jumlah 71 soal. Hasil penelitian menyimpulkan bahwa kompetensi pedagogik guru Sekolah Dasar Negeri 168 Kota Pekanbaru secara keseluruhan mencapai $87.62 \%$ dengan kategori baik sekali. Jumlah kompetensi inti yang memperoleh nilai pada interval 85-100 dengan kategori "Baik Sekali" berjumlah 7 kompetensi inti, jumlah kompetensi inti yang memperoleh nilai pada interval 70-84 dengan kategori "Baik" berjumlah 4 kompetensi inti, jumlah kompetensi inti yang memperoleh nilai pada interval 50-69 dengan kategori "Cukup" berjumlah 0 kompetensi inti, dan jumlah kompetensi inti yang memperoleh nilai pada interval 0-49 dengan kategori "Kurang" berjumlah 0 kompetensi inti.
\end{abstract}

Kata Kunci: kompetensi pedagogik guru

\begin{tabular}{|c|c|c|}
\hline Submitted & Accepted & Published \\
\hline 29 Juli 2020 & 15 April 2021 & 14 September 2021 \\
\hline
\end{tabular}

\begin{tabular}{|l|c|c|}
\hline Citation & $:$ & $\begin{array}{r}\text { Puspitaningsari, A., \& Zufriady, Z. (2021). Teachers' Pedagogic Competence at Sekolah Dasar Negeri 168 Pekanbaru. } \\
\text { Jurnal PAJAR (Pendidikan dan Pengajaran), 5(5), 1202-1210. DOI : http://dx.doi.org/10.33578/pir.v5i5.8076. }\end{array}$ \\
\hline
\end{tabular}

\section{PENDAHULUAN}

Guru adalah pendidik profesional dengan tugas utama yaitu mendidik, mengajar, membimbing, mengarahkan, melatih, menilai, dan mengevaluasi peserta didik pada pendidikan anak usia dini jalur pendidikan formal, pendidikan dasar, dan pendidikan menengah (UU No.14 Tahun 2005). Dalam dunia pendidikan, keberadaan peran dan fungsi guru sangat signifikan dalam usaha peningkatan mutu pendidikan. Berdasarkan Permendiknas nomor 16 tahun 2007 tentang standar kompetensi professional yang harus dimiliki oleh guru, terdapat empat kompetensi yang harus dimiliki oleh guru, yaitu: kompetensi pedagogik, kompetensi professional, kompetensi sosial, dan kompetensi kepribadian. 
Beberapa penelitian sebelumnya telah banyak melakukan penelitian tentang profesionalitas guru menemukan bahwa guru yang profesional (memenuhi standar tenaga pendidik) dapat melaksanakan tugas dan fungsinya sebagai guru dengan maksimal (Nofrico Efendi, 2013). Peni Darmawan (2016) menyatakan bahwa guru secara mutlak harus mempunyai keempat kompetensi, yaitu kompetensi pedagogik, profesional, sosial dan kepribadian hal ini dikarenakan kesuksesan dalam proses pelaksanaan pendidikan ditentukan oleh guru yang professional.

Kompetensi utama yang harus dimiliki guru adalah kompetensi pedagogik, guru harus belajar secara maksimal untuk menguasai kompetensi pedagogik ini baik secara teori dan praktik. Dari sinilah, perubahan dan kemajuan dalam pendidikan akan terjadi dengan pesat. Menurut Antonius (2016) kompetensi pedagogik adalah kemampuan guru dalam mengelola pembelajaran. Kompetensi Pedagogik merupakan kompetensi khas, yang akan membedakan guru dengan profesi lainnya dan akan menentukan tingkat keberhasilan proses dan hasil pembelajaran peserta didiknya (Muhammad Nailul Huda, 2018). Hal tersebut dapat menjadi gambaran bahwa tinggi rendahnya kompetensi pedagogik sangat berpengaruh terhadap pelaksanaan proses pembelajaran di sekolah. Nio Wicak Kuncoro (2013) menyatakan bahwa apabila kompetensi pedagogik seorang guru baik maka hasil belajar yang diperoleh siswa juga akan baik, sedangkan apabila kompetensi pedagogik guru masih kurang baik maka hasil belajar yang diperoleh siswa akan kurang baik pula. Kewajiban bagi guru untuk memiliki kompetensi pedagogik sebenarnya telah sangat jelas, mengingat hal ini sudah ada dalam Undang-Undang Guru dan Dosen No.14 Tahun 2005, yaitu bahwa setiap guru wajib memiliki kompetensi pedagogik.

Menurut Peraturan Menteri Pendidikan Nasional (Permendiknas) No.16 Tahun 2007 menjelaskan bahwa guru pada Sekolah Dasar atau Madrasah Ibtidaiyah (SD/MI), atau bentuk lain yang sederajat, harus memiliki kualifikasi akademik pendidikan minimum diploma empat (D-IV) atau sarjana (S1) dalam bidang pendidikan
Sekolah Dasar atau Madrasah Ibtidaiyah (D-IV/S1 PGSD/MI) atau psikologi yang diperoleh dari program studi yang terakreditasi, sedangkan standar uji kompetensi pedagogik guru dikembangkan dari Permendiknas No.16 Tahun 2007 tentang standar kualifikasi akademik dan kompetensi guru secara utuh dari sepuluh indikator inti kompetensi pedagogik yaitu: a) menguasai karakteristik peserta didik dari aspek fisik, moral, sosial, kultural, emosional, dan intelektal; b) menguasai teori belajar dan prinsipprinsip pembelajaran yang mendidik; c) mengembangkan kurikulum yang terkait dengan mata pelajaran/bidang pengembangan yang diampu; d) menyelenggarakan pembelajaran yang mendidik; e) memanfaatkan teknologi informasi dan komunikasi untuk kepentingan pembelajaran; f) memfasilitasi pengembangan potensi peserta didik untuk mengaktualisasikan berbagai potensi yang dimiliki; g) berkomunikasi secara efektif, empatik, dan santun dengan peserta didik; h) menyelenggarakan penilaian dan evaluasi proses dan hasil belajar; i) memanfaatkan hasil penilaian dan evaluasi untuk kepentingan pembelajaran; dan j) melakukan tindakan reflektif untuk peningkatan kualitas pembelajaran.

Berdasarkan informasi yang diperoleh dari kepala sekolah SD Negeri 168 Pekanbaru, kompetensi guru SD tersebut sudah terbilang baik. Hal ini didasarkan pada hasil supervisi yang telah dilakukan oleh kepala sekolah menunjukkan bahwa kompetensi guru khususnya kompetensi pedagogik memperoleh hasil yang baik. Hal ini dinilai dalam proses pembelajaran yang dilaksanakan guru. Guru SD tersebut dapat melaksanakan proses pembelajaran dengan baik dan dapat melaksanakan komponen kompetensi pedagogik dengan baik. Padahal jika dilihat dari pendidikan guru SD tersebut tidak semuanya berasal dari jurusan Pendidikan Guru Sekolah Dasar (PGSD), tetapi ada beberapa yang berasal dari jurusan Pendidikan Agama Islam, Pendidikan Agama Kristen, dan Pendidikan Jasmani dan Kesehatan. SD Negeri 168 Pekanbaru juga memiliki nilai rata-rata ujian cukup baik. Prestasi akademik dan keberhasilan belajar peserta didik ini sangat dipengaruhi oleh kompetensi yang dimiliki oleh guru secara umum, dan lebih khusus 
lagi oleh guru yang mengemban amanat khusus untuk meningkatkan pemahaman, penghayatan, dan pengalaman peserta didik terhadap pelajaran.

\section{METODE PENELITIAN}

Penelitian ini telah dilaksanakan di Sekolah Dasar Negeri 168 Kota Pekanbaru pada bulan Juli 2020. Jenis penelitian adalah kuantitatif. Sugiyono (2013) menyatakan bahwa penelitian kuantitatif merupakan penelitian yang berlandaskan pada filsafat positivisme, digunakan untuk meneliti pada populasi atau sampel tertentu, pengumpulan data menggunakan instrumen penelitian, analisis data bersifat kuantitatif/statistik. Penelitian bertujuan untuk memberikan gambaran tentang keadaan yang sedang berlangsung pada objek penelitian yaitu tentang Analisis Kompetensi Pedagogik Guru Sekolah Dasar Negeri 168 Kota Pekanbaru. Pengambilan sampel dalam penelitian ini menggunakan teknik sampling jenuh. Sampel yang digunakan yaitu seluruh guru Sekolah Dasar Negeri 168 Kota Pekanbaru yang berjumlah 15 orang guru. Data dalam penelitian ini adalah data tentang kompetensi pedagogik guru diambil langsung dari guru SD Negeri 168 Kota Pekanbaru yaitu 15 orang guru. Data ini dikumpulkan dengan menggunakan angket melalui media google form mengenai kompetensi pedagogik guru.

Teknik analisis data yang digunakan melalui beberapa tahapan yaitu: uji validitas, uji reliabilitas data dan selanjutnya mengolah data dengan menggunakan rumus persentase sebagai berikut:

$\mathrm{N}=\frac{F}{S} \times 100 \%$

Keterangan:

$\mathrm{N} \quad$ : Nilai yang diperoleh

F : Jumlah skor didapat

S : Jumlah skor maksimal

100 : Bilangan tetap

Sumber: Akson dan Sahlan (2005)

\section{HASIL DAN PEMBAHASAN}

Setelah data kompetensi pedagogik guru diolah, selanjutnya penyajian hasil penelitian tentang kompetensi pedagogik guru SD Negeri 168 Pekanbaru secara detail pada setiap indikator pada sepuluh kompetensi inti pada kompetensi pedagogik. Adapun hasil penelitian tentang perolehan data kompetensi pedagogik adalah sebagai berikut.

\section{Kompetensi Pedagogik Guru Sekolah Dasar Negeri 168 Kota Pekanbaru}

Adapun perolehan data tentang kompetensi pedagogik guru Sekolah Dasar Negeri 168 Kota Pekanbaru dapat dilihat pada tabel 1 di bawah.

Tabel 1. Kompetensi Pedagogik Guru Sekolah Dasar Negeri 168 Pekanbaru

\begin{tabular}{cccccc}
\hline Interval & Kategori & $\begin{array}{c}\text { Jumlah } \\
\text { Guru }\end{array}$ & $\begin{array}{c}\text { Jumlah Guru } \\
\text { Keseluruhan }\end{array}$ & Rata-rata & Ketegori \\
\hline $85-100$ & Baik Sekali & 11 & 15 & $87.62 \%$ & Baik Sekali \\
$70-84$ & Baik & 4 & & & \\
$50-69$ & Cukup & 0 & & & \\
$0-49$ & Kurang & 0 & & & \\
\hline
\end{tabular}

Berdasarkan tabel di atas, diketahui bahwa jumlah guru yang memperoleh nilai pada interval 85-100 dengan kategori "Baik Sekali" berjumlah 11 guru, jumlah guru yang memperoleh nilai pada interval 70-84 dengan kategori "Baik" berjumlah 4 guru, jumlah guru yang memperoleh nilai pada interval 50-69 dengan kategori "Cukup" berjumlah 0 guru, dan jumlah guru yang memperoleh nilai pada interval 0-49 dengan kategori "Kurang" berjumlah 0 guru. Rata-rata 
perolehan nilai kompetensi pedagogik guru sebesar $87.62 \%$ dengan kategori "Baik Sekali”.

\section{Analisis Per-Indikator Kompetensi Pedagogik Guru Sekolah Dasar Negeri 168 Kota Pekanbaru}

Berdasarkan Permendiknas No. 16 Tahun 2007 tentang standar kompetensi guru SD/MI menyatakan bahwa kompetensi pedagogik terdiri dari 10 kompetensi inti. Adapun perolehan hasil per-indikator tentang kompetensi pedagogik dapat dilihat pada tabel 2 di bawah ini.

Tabel 2. Kompetensi Pedagogik Guru Sekolah Dasar Negeri 168 Kota Pekanbaru Per-Kompetensi Inti

\begin{tabular}{clcc}
\hline No & \multicolumn{1}{c}{ Kompetensi Inti } & Persentase & Kategori \\
\hline 1 & $\begin{array}{l}\text { Menguasai karakteristik peserta didik dari aspek } \\
\text { fisik, moral, sosial, kultural, emosional, dan } \\
\text { intelektual. }\end{array}$ & $95.20 \%$ & Baik Sekali \\
\hline 2 & $\begin{array}{l}\text { Menguasai teori belajar dan prinsip-prinsip } \\
\text { pembelajaran yang mendidik. }\end{array}$ & 85 & Baik Sekali \\
\hline 3 & $\begin{array}{l}\text { Mengembangkan kurikulum yang terkait dengan } \\
\text { mata pelajaran/bidang pengembangan yang } \\
\text { diampu. }\end{array}$ & $86.85 \%$ & Baik Sekali \\
\hline 4 & $\begin{array}{l}\text { Menyelenggarakan pembelajaran yang mendidik. } \\
\text { Memanfaatkan teknologi informasi dan } \\
\text { komunikasi potensi peserta didik untuk } \\
\text { mengaktualisasi berbagai potensi yang dimiliki. }\end{array}$ & $86.61 \%$ & Baik Sekali \\
\hline 6 & $\begin{array}{l}\text { Memfasilitasi pengembangan potensi peserta } \\
\text { didik untuk mengaktualisasikan berbagai potensi } \\
\text { yang dimiliki. }\end{array}$ & 81.25 & Baik \\
\hline 7 & $\begin{array}{l}\text { Berkomunikasi secara efektif, empatik, dan } \\
\text { santun dengan peserta didik. }\end{array}$ & Baik Sekali \\
\hline 8 & $\begin{array}{l}\text { Menyelenggarakan penilaian dan evaluasi proses } \\
\text { dan hasil belajar. }\end{array}$ & 86.38 & Baik \\
\hline 9 & $\begin{array}{l}\text { Memanfaatkan hasil penilaian dan evaluasi untuk } \\
\text { kepentingan pembelajaran. }\end{array}$ & $\begin{array}{l}\text { Melakukan tindakan reflektif untuk peningkatan } \\
\text { kualitas pembelajaran. }\end{array}$ & Baik Sekali \\
\hline 10 & 79.44 & Baik \\
\hline
\end{tabular}

Menguasai karakteristik peserta didik dari aspek fisik, moral, sosial, kultural, emosional, dan intelektual

Data penelitian mengenai kompetensi pedagogik guru dalam menguasai karakteristik peserta didik dari aspek fisik, moral, sosial, kultural, emosional, dan intelektual terdiri dari 4 indikator yaitu (a) memahami karakteristik peserta didik usia sekolah dasar yang berkaitan dengan aspek fisik, intelektual, sosial-emosional, moral, spiritual, dan latar belakang sosial-budaya, (b) mengidentifikasi potensi peserta didik usia sekolah dasar dalam lima mata pelajaran SD/MI, (c) mengidentifikasi kemampuan awal peserta didik usia sekolah dasar dalam lima mata pelajaran SD/MI, dan (d) mengidentifikasi kesulitan peserta belajar usia sekolah dasar dalamlima mata pelajaran SD/MI.

Adapun perolehan data pada masingmasing indikator dapat dilihat pada tabel 3 di bawah ini. 
Tabel 3. Kompetensi Pedagogik Guru pada Kompetensi Menguasai Karakteristik Peserta Didik dari Aspek Fisik, Moral, Sosial, Kultural, Emosional, dan Intelektual

\begin{tabular}{ccccccc}
\hline No & Keterangan & $\begin{array}{c}\text { Jumlah } \\
\text { Soal }\end{array}$ & Persentase & Rata-rata & Kategori & $\begin{array}{c}\text { Jumlah } \\
\text { Responden }\end{array}$ \\
\hline 1 & Indikator 1 & 2 & 95.83 & & & \\
2 & Indikator 2 & 2 & 95.83 & 95.20 & Baik & 15 \\
3 & Indikator 3 & 3 & 91.66 & & Sekali & \\
4 & Indikator 4 & 2 & 97.5 & & & \\
\hline
\end{tabular}

Menguasai teori belajar dan prinsip-prinsip pembelajaran yang mendidik

Data penelitian mengenai kompetensi pedagogik guru dalam menguasai teori belajar dan prinsip-prinsip pembelajaran yang mendidik terdiri dari 3 indikator yaitu (a) memahami berbagai teori belajar dan prinsip-prinsip pembelajaran yang mendidik terkait dengan lima mata pelajaran SD/MI, (b) menerapkan berbagai pendekatan, strategi, metode, dan teknik pembelajaran yang mendidik secara kreatif dalam lima mata pelajaran SD/MI, dan (c) menerapkan pendekatan pembelajaran tematis, khususnya di kelas-kelas awal SD/MI.

Adapun perolehan data pada masingmasing indikator dapat dilihat pada tabel $4 \mathrm{di}$ bawah ini.

Tabel 4. Kompetensi Pedagogik Guru pada Kompetensi Menguasai Teori Belajar dan PrinsipPrinsip Pembelajaran yang Mendidik

\begin{tabular}{ccccccc}
\hline No & Keterangan & $\begin{array}{c}\text { Jumlah } \\
\text { Soal }\end{array}$ & Persentase & Rata-rata & Kategori & $\begin{array}{c}\text { Jumlah } \\
\text { Responden }\end{array}$ \\
\hline 1 & Indikator 1 & 1 & 80 & & Baik & 15 \\
2 & Indikator 2 & 2 & 87.5 & 85 & Sekali & \\
3 & Indikator 3 & 2 & 87.5 & & \\
\hline
\end{tabular}

Mengembangkan kurikulum yang terkait dengan mata pelajaran/bidang pengembangan yang diampu

Data penelitian mengenai kompetensi pedagogik guru dalam mengembangkan kurikulum yang terkait dengan mata pelajaran/bidang pengembangan yang diampu terdiri dari 3 indikator yaitu (a) memahami prinsip-prinsip pengembangan kurikulum, (b) menentukan tujuan lima mata pelajaran SD/MI, dan (c) menentukan pengalaman belajar yang sesuai untuk mencapai tujuan lima mata pelajaran SD/MI.

Adapun perolehan data pada masingmasing indikator dapat dilihat pada tabel 5 di bawah ini.

Tabel 5. Kompetensi Pedagogik Guru pada Kompetensi Mengembangkan Kurikulum yang Terkait dengan Mata Pelajaran/Bidang Pengembangan yang Diampu

\begin{tabular}{ccccccc}
\hline No & Keterangan & $\begin{array}{c}\text { Jumlah } \\
\text { Soal }\end{array}$ & Persentase & Rata-rata & Kategori & $\begin{array}{c}\text { Jumlah } \\
\text { Responden }\end{array}$ \\
\hline 1 & Indikator 1 & 3 & 88.88 & & Baik & 15 \\
2 & Indikator 2 & 2 & 85 & 86.85 & Sekali & \\
3 & Indikator 3 & 3 & 86.66 & & & \\
\hline
\end{tabular}




$\begin{aligned} & \text { Menyelenggarakan Pembelajaran yang } \\ & \text { Mendidik }\end{aligned}$ tujuan lima mata pelajaran SD/MI, (c) menyusun
Data penelitian mengenai kompetensi $\begin{aligned} & \text { kegiatan di dalam kelas, laboratorium, maupun } \\ & \text { lapangan, (d) melaksanakan pembelajaran yang } \\ & \text { pedagogik guru dalam menyelenggarakan } \\ & \text { pembelajaran yang mendidik terdiri dari 5 }\end{aligned} \begin{aligned} & \text { mendidik di kelas, laboratorium, dan lapangan, dan } \\ & \text { indikator yaitu (a) memahami prinsip-prinsip } \\ & \text { perancangan pembelajaran yang mendidik }\end{aligned} \begin{aligned} & \text { dengan karakteristik peserta didik dan lima mata } \\ & \text { memahami priajaran SD/MI untuk mencapai tujuan } \\ & \text { kurikulum, (b) mengembangkan komponen- }\end{aligned}$

komponen rancangan pembelajaran menentukan

Tabel 6. Kompetensi Pedagogik Guru pada Kompetensi Menyelenggarakan Pembelajaran yang Mendidik

\begin{tabular}{ccccccc}
\hline No & Keterangan & $\begin{array}{c}\text { Jumlah } \\
\text { Soal }\end{array}$ & Persentase & Rata-rata & Kategori & $\begin{array}{c}\text { Jumlah } \\
\text { Responden }\end{array}$ \\
\hline 1 & Indikator 1 & 2 & 87.5 & & & \\
2 & Indikator 2 & 3 & 91.66 & & Baik & 15 \\
3 & Indikator 3 & 3 & 88.88 & 86.61 & Sekali & \\
4 & Indikator 4 & 2 & 74.16 & & & \\
5 & Indikator 5 & 2 & 90.83 & & & \\
\hline
\end{tabular}

Memanfaatkan teknologi informasi dan komunikasi potensi peserta didik untuk mengaktualisasi berbagai potensi yang dimiliki

Data penelitian mengenai kompetensi pedagogik guru dalam memanfaatkan teknologi informasi dan komunikasi potensi peserta didik untuk mengaktualisasi berbagai potensi yang dimiliki terdiri dari 1 indikator yaitu (a) memanfaatkan teknologi informasi dan komunikasi untuk mengaktualisasi berbagai potensi yang dimiliki.

Adapun perolehan data pada masingmasing indikator di atas dapat dilihat pada tabel 7 di bawah ini.

Tabel 7. Kompetensi Pedagogik Guru pada Kompetensi Memanfaatkan Teknologi Informasi dan Komunikasi Potensi Peserta Didik untuk Mengaktualisasi Berbagai Potensi yang Dimiliki

\begin{tabular}{ccccccc}
\hline No & Keterangan & $\begin{array}{c}\text { Jumlah } \\
\text { Soal }\end{array}$ & Persentase & Rata-rata & Kategori & $\begin{array}{c}\text { Jumlah } \\
\text { Responden }\end{array}$ \\
\hline 1 & Indikator 1 & 3 & 87.77 & 87.77 & $\begin{array}{c}\text { Baik } \\
\text { Sekali }\end{array}$ & 15 \\
\hline
\end{tabular}

\begin{abstract}
Memfasilitasi Pengembangan Potensi Peserta Didik Untuk Mengaktualisasikan Berbagai Potensi yang Dimiliki

Data penelitian mengenai kompetensi pedagogik guru dalam memfasilitasi pengembangan potensi peserta didik untuk mengaktualisasikan berbagai potensi yang dimiliki terdiri dari 2 indikator yaitu (a) menyediakan
\end{abstract}

berbagai kegiatan pembelajaran untuk, mendorong peserta didik mencapai prestasi belajar secara optimal, dan (b) menyediakan berbagai kegiatan pembelajaran untuk mengaktualisasi potensi peserta diduk, termasuk kreativitasnya.

Adapun perolehan data pada masingmasing indikator dapat dilihat pada tabel 8 di bawah ini. 
Tabel 8. Kompetensi Pedagogik Guru pada Kompetensi Memfasilitasi Pengembangan Potensi Peserta Didik untuk Mengaktualisasikan Berbagai Potensi yang Dimiliki

\begin{tabular}{ccccccc}
\hline No & Keterangan & $\begin{array}{c}\text { Jumlah } \\
\text { Soal }\end{array}$ & Persentase & Rata-rata & Kategori & $\begin{array}{c}\text { Jumlah } \\
\text { Responden }\end{array}$ \\
\hline 1 & Indikator 1 & 2 & 88.33 & 81.25 & Baik & 15 \\
2 & Indikator 2 & 2 & 74.16 & & & \\
\hline
\end{tabular}

Berkomunikasi Secara Efektif, Empatik, dan Santun dengan Peserta Didik

Data penelitian mengenai kompetensi pedagogik guru dalam berkomunikasi secara efektif, empatik, dan santun dengan peserta didik terdiri dari 2 indikator yaitu (a) memahami berbagai strategi berkomunikasi secara efektif, empatik dan santun, baik secara lisan maupun tulisan, dan (b) berkomunikasi secara efektif, empatik, dan santun dengan perserta didik dengan bahasa yang khas dalam interaksi pembelajaran.

Tabel 9. Kompetensi Pedagogik Guru pada Kompetensi Berkomunikasi Secara Efektif, Empatik, dan Santun dengan Peserta Didik

\begin{tabular}{ccccccc}
\hline No & Keterangan & $\begin{array}{c}\text { Jumlah } \\
\text { Soal }\end{array}$ & Persentase & Rata-rata & Kategori & $\begin{array}{c}\text { Jumlah } \\
\text { Responden }\end{array}$ \\
\hline 1 & Indikator 1 & 3 & 97.77 & 96.38 & $\begin{array}{c}\text { Baik } \\
\text { Sekali }\end{array}$ & 15 \\
\hline
\end{tabular}

Menyelenggarakan Penilaian dan Evaluasi Proses dan Hasil Belajar

Data penelitian mengenai kompetensi pedagogik guru dalam menyelenggarakan penilaian dan evaluasi proses dan hasil belajar terdiri dari 7 indikator yaitu (a) memahami prinsipprinsip penilaian dan evaluasi proses dan hasil belajar sesuai dengan karakteristik lima mata pelajaran SD/MI, (b) menentukan aspek-aspek proses dan hasil belajar yang penting untuk dinilai dan dievaluasi sesuai dengan karakteristik lima mata pelajaran SD/MI, (c) menentukan prosedur penilaian dan evaluasi proses dan hasil belajar, (d) mengembangkan instrumen penilaian dan evaluasi proses dan hasil belajar, (e) mengadministrasikan penilaian proses dan hasil belajar secara berkesinambungan dengan menggunakan instrument, (f) menganalisis hasil penilaian proses dan hasil belajar untuk berbagai tujuan, dan (g) melakukan evaluasi proses dan hasil belajar.

Adapun perolehan data pada masingmasing indikator dapat dilihat pada tabel $10 \mathrm{di}$ bawah ini.

Tabel 10. Kompetensi Pedagogik Guru pada Kompetensi Menyelenggarakan Penilaian dan Evaluasi Proses dan Hasil Belajar

\begin{tabular}{ccccccc}
\hline No & Keterangan & $\begin{array}{c}\text { Jumlah } \\
\text { Soal }\end{array}$ & Persentase & Rata-rata & Kategori & $\begin{array}{c}\text { Jumlah } \\
\text { Responden }\end{array}$ \\
\hline 1 & Indikator 1 & 3 & 87.22 & & & \\
2 & Indikator 2 & 2 & 90.83 & & & \\
3 & Indikator 3 & 3 & 85 & & & \\
4 & Indikator 4 & 2 & 80 & 84.64 & Baik & 15 \\
5 & Indikator 5 & 3 & 82.77 & & & \\
6 & Indikator 6 & 3 & 83.33 & & & \\
7 & Indikator 7 & 1 & 83.33 & & & \\
\hline
\end{tabular}


Memanfaatkan Hasil Penilaian dan Evaluasi Untuk Kepentingan Pembelajaran

Data penelitian mengenai kompetensi pedagogik guru dalam memanfaatkan hasil penilaian dan evaluasi untuk kepentingan pembelajaran terdiri dari 2 indikator yaitu (a) menggunakan informasi hasil penilaian dan evaluasi untuk menentukan ketuntasan belajar, dan (b) menggunakan informasi hasil penilaian dan evaluasi untuk merancang program remedial dan pengayaan.

Adapun perolehan data pada masingmasing indikator dapat dilihat pada tabel $11 \mathrm{di}$ bawah ini.

Tabel 11. Kompetensi Pedagogik Guru pada Kompetensi Memanfaatkan Hasil Penilaian dan Evaluasi untuk Kepentingan Pembelajaran

\begin{tabular}{ccccccc}
\hline No & Keterangan & $\begin{array}{c}\text { Jumlah } \\
\text { Soal }\end{array}$ & Persentase & Rata-rata & Kategori & $\begin{array}{c}\text { Jumlah } \\
\text { Responden }\end{array}$ \\
\hline 1 & Indikator 1 & 3 & 91.66 & 90 & Baik & 15 \\
2 & Indikator 2 & 3 & 88.33 & & Sekali & 15 \\
\hline
\end{tabular}

\begin{abstract}
Melakukan Tindakan Reflektif untuk Peningkatan Kualitas Pembelajaran

Data penelitian mengenai kompetensi pedagogik guru dalam melakukan tindakan reflektif untuk peningkatan kualitas pembelajaran

terdiri dari 1 indikator yaitu (a) melakukan refleksi terhadap pembelajaran yang telah dilaksanakan.

Adapun perolehan data pada masingmasing indikator dapat dilihat pada tabel $12 \mathrm{di}$ bawah ini.
\end{abstract}

Tabel 12. Kompetensi Pedagogik Guru pada Kompetensi Melakukan Tindakan Reflektif untuk Peningkatan Kualitas Pembelajaran

\begin{tabular}{ccccccc}
\hline No & Keterangan & $\begin{array}{c}\text { Jumlah } \\
\text { Soal }\end{array}$ & Persentase & Rata-rata & Kategori & $\begin{array}{c}\text { Jumlah } \\
\text { Responden }\end{array}$ \\
\hline 1 & Indikator 1 & 3 & 79.44 & 79.44 & Baik & 15 \\
\hline
\end{tabular}

\section{SIMPULAN DAN REKOMENDASI}

Berdasarkan hasil penelitian dan pembahasan, maka penelitian ini dapat disimpulkan bahwa kompetensi pedagogik Guru Sekolah Dasar Negeri 168 Kota Pekanbaru termasuk dalam kategori baik sekali. Hal ini dibuktikan dengan perolehan data kompetensi pedagogik oleh guru, yaitu rata-rata perolehan nilai kompetensi pedagogik guru sebesar $87.62 \%$ dengan kategori "Baik sekali". Jumlah kompetensi inti yang memperoleh nilai pada interval 85-100 dengan kategori "Baik Sekali" berjumlah 7 kompetensi inti yaitu: (1) menguasai karakteristik peserta didik dari aspek fisik, moral, sosial, kultural, emosional, dan intelektual; (2) menguasai teori belajar dan prinsip-prinsip pembelajaran yang mendidik; (3) mengembangkan kurikulum yang terkait dengan mata pelajaran/bidang pengembangan yang diampu; menyelenggarakan pembelajaran yang mendidik; (5) memanfaatkan teknologi informasi dan komunikasi potensi peserta didik untuk mengaktualisasi berbagai potensi yang dimiliki; (6) berkomunikasi secara efektif, empatik, dan santun dengan peserta didik; dan (7) memanfaatkan hasil penilaian dan evaluasi untuk kepentingan pembelajaran. Jumlah kompetensi inti yang memperoleh nilai pada interval 70-84 dengan kategori "Baik" berjumlah 3 kompetensi inti yaitu: (1) memfasilitasi pengembangan potensi peserta didik untuk mengaktualisasikan berbagai potensi yang dimiliki; (2) menyelenggarakan penilaian dan evaluasi proses dan hasil belajar; dan (3) melakukan tindakan reflektif untuk peningkatan kualitas pembelajaran. Jumlah kompetensi inti yang memperoleh nilai pada interval 50-69 dengan kategori "Cukup" berjumlah 0 kompetensi inti, dan jumlah 
kompetensi inti yang memperoleh nilai pada interval 0-49 dengan kategori "Kurang" berjumlah 0 kompetensi inti.

Adapun rekomendasi yang ingin peneliti sampaikan sehubungan dengan kompetensi pedagogik guru yaitu:

1. Sebaiknya guru-guru tetap mempertahankan kualitas kompetensi pedagogik yang dimiliki dan untuk kedepannya bisa lebih meningkatkan lagi kualitas kompetensi pedagogiknya agar proses pembelajaran menjadi lebih baik.

2. Hasil penelitian ini kiranya dapat dijadikan pedoman dan dasar guna bagi peneliti yang berminat untuk mengembangkan hasil penelitian ini dalam ruang lingkup yang lebih luas dan mendalam.

\section{DAFTAR PUSTAKA}

Akson dan Sahlan. (2005). Aplikasi Statistika dan Metode Penelitiain untuk Administrasi dan Manajemen. Bandung: Dewa Ruci.

Antonius. (2016). Buku Pedoman Guru. Bandung: Yrama Widya.

Arikunto, S. (2014). Prosedur Penelitian, Suatu Pendekatan Praktik. Jakarta: PT Rineka Cipta.

Asmara, H. (2015). Profesi Kependidikan. Bandung: Alfabeta.

Darmawan, P. (2016). Analisis Kompetensi Profesional Guru Sekolah Dasar Negeri Gugus II Kecamatan Marpoyan Damai Kota Pekanbaru. Jurnal Online Mahasiswa FKIP Univeritas Riau. (Online). https://jom.unri.ac.id/index.php/JOMFKI $\mathrm{P} /$ issue/view/364. (Diakses pada tanggal 20 Juni 2020)

Efendi, N. (2013). Analisis Profesionalitas Guru Sekolah Dasar Se-Kecamatan Tampan Kota Pekanbaru. Jurnal Online Mahasiswa FKIP Univeritas Riau. (Online).

https://jom.unri.ac.id/index.php/JOMFKI

P/issue/view/217. (Diakses pada tanggal 28 Juli 2020)

Huda, M. N. (2018). Kompetensi Pedagogik Mahasiswa Program Studi Pendidikan
Guru Sekolah Dasar. Jurnal Online Mahasiswa FKIP Universitas Riau. (Online).

https://jom.unri.ac.id/index.php/JOMFKI P/article/view/17835/17226. (Diakses pada tanggal 20 Juni 2020)

Kuncoro, N. W. (2013). Hubungan Kompetensi Pedagogik Guru dengan Hasil Belajar IPS Siswa. Portal Garuda. (Online). http://download.portalgaruda.org/article.p hp? article $=288944 \&$ val $=7239 \&$ title $=H$

UBUNGAN\%20KOMPETENSI\%20PED AGOGIK\%20GURU\%20DENGAN\% 20HASIL \%20BELAJAR\%20IPS\%20SIS WA. (Diakses pada tanggal 28 Juli 2020)

Kurniasih, I., dan Sani, B. (2015). Sukses Uji Kompetensi Guru Panduan lengkap. Surabaya: Kata Pena.

Kurniasih, I., dan Sani, B. (2017). Kupas Tuntas Kompetensi Pedagogik Teori dan Praktik. Surabaya: Kata Pena.

Mulyasa. (2007). Menjadi Guru Profesional, Menciptakan Pembelajaran Kreatif dan Menyenangkan. Bandung: PT. Remaja Rosdakarya.

Mulyasa. (2012). Standar Kompetensi dan Sertifikasi Guru. Bandung: PT. Remaja Rosdakarya.

Slameto. (2003). Belajar dan Faktor-Faktor yang mempengaruhinya. Jakarta: Rineka Cipta.

Sugiyono. (2013). Metode Penelitian Kuantitatif Kualitatif dan R\&D. Bandung: Alfabeta.

Sumirat, F. (2015). Analisis Kompetensi Guru Sekolah Dasar Dalam Mengembangkan Kurikulum dan Rancangan Pembelajaran SD Ar-Rafi' Kota Bandung. Jurnal Universitas Islam 45.3:2035.Universitas Islam 45. Bekasi.

Zulfah. (2016). 99,9\% Lulus UjiKompetensi Guru $(U K G)$. Yogyakarta: Bright Publisher. 